\title{
Management of foliar application of fungicides to enhance physiological and sanitary quality of soybean seeds
}

\author{
Everton Vinicius Zambiazzi ${ }^{1}$, Adriano Teodoro Bruzi ${ }^{1}$, Maria Laene Moreira de Carvalho ${ }^{1}$, Scheila Roberta \\ Guilherme $^{2}$, Alan Mario Zuffo ${ }^{3 *}$, Alan Eduardo Seglin Mendes ${ }^{1}$, Ana Paula de Sales ${ }^{1}$, Flaviane de Oliveira \\ Ribeiro $^{2}$, Mariane Cristina Bianchi ${ }^{2}$, Igor Oliveri Soares ${ }^{1}$ and Isabela Maria Monteiro Borges ${ }^{1}$
}

${ }^{1}$ Department of Agriculture, Federal University of Lavras, 37200-000, Lavras, Minas Gerais, Brazil

${ }^{2}$ Department of Biology Federal University of Lavras, 37200-000, Lavras, Minas Gerais, Brazil

${ }^{3}$ Department of Crop Production, State University of Mato Grosso do Sul, 79540-000, Cassilândia, Mato Grosso do Sul, Brazil

\section{*Corresponding author: alan_zuffo@hotmail.com}

\begin{abstract}
Controlling disease in the soybean crop is essential for obtaining high quality seeds and high yield. This leads the producer to increase the number of fungicide applications as a preventive measure. The aim of this study was to evaluate soybean response to increase in the number of foliar applications of different chemical fungicides during crop development to enhance the physiological and sanitary quality of soybean seeds. The experiment was performed in the state of Minas Gerais, Brazil, in two environments (ljaci and Lavras) in the 2014/15 crop year, with the cultivar BRSMG $850 \mathrm{G}_{\mathrm{RR}}$. The field experiment was conducted in randomized blocks in split-plots, with three replications. The plots were composed of the number of applications $(0,1,2,3,4$ and 5 times). The applications started at the $R_{1}$ stage (beginning of bloom), with a 15-day interval to the next application $\left(R_{1} ; R_{1}+15 d ; R_{1}+30 d ; R_{1}+45 d\right.$; $\mathrm{R}_{1}+60 \mathrm{~d}$ ). The split-plots were constituted by the different chemical fungicides (Elatus, Fox ${ }^{\circ}$, Opera ${ }^{\circ}$, Orkestra , and an unregistered product - BAS - 702). Seeds were evaluated soon after harvest and after eight months of storage. The following characteristics were evaluated: seed water content, germination in paper and sand substrates, emergence, emergence speed index, mechanical damage in the sodium hypochlorite test, electrical conductivity, accelerated aging, seed vigor and viability by the tetrazolium test, and seed health, using a completely randomized design. Regardless of which fungicide was used, an increase in the number of foliar applications of fungicides, up to five applications, leads to an increase in the physiological and sanitary quality of soybean seeds, both those newly harvested and those stored for eight months. However, Fox fungicide (trifloxystrobin + prothioconazole) applied on the leaf during the reproductive stages of the soybean crop brought about the best results in the physiological quality of newly harvested seeds and seeds stored for eight months, as well as in the sanitary quality of newly harvested seeds.
\end{abstract}

Keywords: Glycine max (L.) Merrill, phytosanitary control, seed pathology, vigor, viability.

Abbreviations: INMET_National Institute of Meteorology; $\mathrm{R}_{1}$ stage beginning bloom; WC between the number of applications and water content; GS germination in sand; G_germination; SE_seedling emergence; ESI_emergence speed index; $M D H_{-}$mechanical damage by the sodium hypochlorite test; EC_electrical conductivity; AA_accelerated aging; VIG_tetrazolium test seed vigor; VIA tetrazolium test seed viability.

\section{Introduction}

Due to the considerable importance of soybean in Brazilian agribusiness, studies on the factors that limit maximum expression of its yield potential are necessary. Diseases are a prominent factor, subjecting soybean to pressures that can significantly reduce yield (Quinebre, 2014) and seed quality (Carmona and Reis, 2009) through reduction in ability to produce photoassimilates, thus impairing seed formation (Bethenod et al., 2005). Approximately 40 diseases caused by fungi, bacteria, nematodes, and viruses have been identified in Brazil (Finoto et al., 2011; Vello and Carvalho, 2013). This number continues to increase due to expansion of the crop to new areas. The economic importance of each disease varies from one crop year to another and one region to another, depending on the weather conditions of each season (EMBRAPA, 2010).

Diseases in soybean can be controlled through adequate management techniques, such as the use of chemical fungicides, which have led to relevant results for the purpose of maintaining yield potential and seed quality (Marzari et al., 2007). Under wetter climate conditions, disease control through foliar fungicides can result in gain in seed quality because fungicides not only protect leaves but also preserve the integrity of pods, which, for their part, provide better protection to the seeds against adverse climate/weather conditions (Krzyzanowski et al., 2015). 
The application of foliar fungicides is the most effective and immediate means of control when plants are already established in the field. Application of fungicides in a preventive manner has stood out as the most effective strategy in control of diseases (Azevedo, 2001). A longer residual period and better performance of fungicides were obtained by Vitti et al. (2004) as a result of preventive application. Thus, in recent crop seasons, the number of fungicide applications on the soybean crop has grown. In these crop seasons, four applications of fungicides were made on average, a number considered high for disease management, which foresees an average of two to three applications (Martins, 2009).

Among the inputs in the agricultural sector, high quality seed plays a fundamental role in the entire production system that aims for optimization of quantitative and qualitative standards (Silveira, 2010). When all the aspects involved in seed quality and the effects of these aspects on implementation and yield of the soybean crop are analyzed, the fundamental importance of using high quality seeds of known origin becomes clear (França Neto et al., 2010).

Diverse fungicides have been registered for soybean in the Brazilian market, with different active ingredients. However, information that associates seed quality with the active ingredients available on the market for leaf application is limited. This lack of information is related to the introduction of new fungicides. Thus, with the aim of obtaining efficiency in disease control, along with high quality seeds, producers have used different products and have increased the number of fungicide applications on the crop.

In light of the above, the aim of this study was to evaluate the physiological and sanitary quality of soybean seeds, both newly harvested and after storage, in accordance with an increase in the number of foliar applications in production fields. Different fungicides for the crop were analyzed with a view toward optimizing the plant protection period.

\section{Results and Discussion}

Analysis of variance (Supplementary Table 1) indicates significant differences in physiological potential between the production locations, the number of applications, and the fungicides for the two periods of evaluation.

Previous knowledge of the initial water content of the seeds is important in performing quality tests since uniformity of seed water content is indispensable for standardizing evaluations and obtaining consistent results (Marcos Filho, 1999). The results obtained were similar in the two periods of evaluation, with variation of $11 \%$ for seeds evaluated soon after harvest and $10.5 \%$ for stored seeds (Supplementary Table 1).

\section{Effect of Production Environment}

Seeds produced in the environment of Lavras had better quality than seeds in the environment of ljaci (Table 3). This is a result of lower rainfall in the crop field in Lavras (Figure 1 ), especially in the reproductive stage, which had an average of $227 \mathrm{~mm}$ less rainfall than in ljaci. This had a positive effect on the quality of seeds produced in the Lavras environment. Initial quality of the seed is a fundamental factor, especially in regard to soybean seed, which, by the nature of its chemical composition, already has low storage potential (Mavaieie, 2014). Preserving seed quality during storage, that is, from harvest up to the time of sowing, is a fundamental aspect to consider in the production process because efforts made in the production phase might not be effective if seed quality is not maintained up to the time of seed use (Oliveira et al., 1999).

\section{Effect of Fungicides}

The use of fungicides applied on leaves during crop development has been the focus of various studies, which show physiological effects on plants but also significant yield gains (Dourado Neto et al., 2005) and beneficial effects on seed quality (Canedo et al., 2013). When fungicides are used, they not only protect the leaves, but also preserve the integrity of the pods, which, for their part, will provide more protection to the seed against adverse weather conditions (Krzyzanowski et al., 2015).

Currently in Brazil, there are diverse fungicides registered for the soybean crop, with different active ingredients. Nevertheless, information that associates seed quality with the active ingredients for foliar application available on the market is limited. Among the different fungicides used in this study, the active ingredients trifloxystrobin + prothioconazole (Fox ${ }^{\oplus}$ ) in general provided better quality, both for seeds evaluated soon after harvest and for stored seeds (Table 3 ). Analysis of physical quality through the hypochlorite test showed that application of this fungicide was related to a higher percentage of mechanical damage. However, this increase in seed damage observed did not compromise seed physiological quality.

All the fungicide treatments exhibited mean seed germination percentages higher than the minimum percentage established for sale of soybean seeds, i.e., $80 \%$ germination (Carraro and Peske, 2005). For the seeds evaluated soon after storage, the results for germination indicate that only the treatments with fungicides with the active ingredients trifloxystrobin + prothioconazole, pyraclostrobin + epoxiconazole, and pyraclostrobin + fluxapyroxad exhibited germination above the minimum levels established for sale of soybean seeds (Table 3). Similar results were observed for germination in sand, emergence, emergence speed index, electrical conductivity, accelerated aging, and vigor and viability by the tetrazolium test. Seeds in these tests exhibited decreased performance after storage, which is shown especially by reduction in the emergence speed index.

It is important to highlight that high quality seeds are important for establishing a crop. Seed performance aspects aim at increasing the germination percentage of agricultural crop species. These processes are directly related to rapid and uniform soil cover, to fast gain in dry matter, and, consequently, higher yield, significantly contributing to gains in seed production (Canedo et al., 2013).

In a study performed by Danelli et al. (2011) evaluating the quality of soybean seeds as affected by foliar treatment in the field, the authors found that the effect of the fungicides applied on the aboveground part of soybean favored seed physiological quality, and the best fungicides were those with the active ingredients pyraclostrobin + epoxiconazole and trifloxystrobin + cyproconazole. Nevertheless, Gagliardi et al. (2009), Pinto et al. (2011), and Brzezinski et al. (2012) 
did not observe an effect of foliar fungicides on the physiological quality of soybean seeds.

\section{Effect of the Number of Applications}

In addition to the use of different active ingredients, some authors report that an increase in the number of applications of foliar fungicides during crop development has led to positive results on yield, as well as on seed quality in general. In relation to the number of applications of chemical fungicides, a similar response was found between evaluations soon after harvest and those after storage, in which an increasing number of preventive applications of fungicides, up to five applications, was essential for maintaining high quality of the seeds produced. An increase in the number of applications strengthened plant immunity to pathogens.

The results are better shown by newly harvested seeds (Figure 2), in which a linear response was found. In comparison to the control, an increase was observed in seed quality with five applications of chemical fungicides. This increase was around 5\% for germination in sand, $9 \%$ for germination (Figure $2 \mathrm{~A}$ ), 12\% for the emergence speed index (Figure 2 B), $7 \%$ for seedling emergence, and $20 \%$ for accelerated aging (Figure $2 \mathrm{C}$ ), as well as $9 \%$ for seed vigor and $7 \%$ for seed viability, in the seeds evaluated by the tetrazolium test (Figure 2 D).

Similar results were found for seeds evaluated after eight months of storage, with increases of around $10 \%$ for germination in sand, $7 \%$ for germination (Figure 3 A), $9 \%$ for electrical conductivity (Figure $3 \mathrm{~B}$ ), $9 \%$ for accelerated aging (Figure $3 \mathrm{C}$ ), and $8 \%$ for seed vigor and $9 \%$ for seed viability in the seeds evaluated by the tetrazolium test (Figure $3 \mathrm{D}$ ).

Similar results were obtained by Gabriel et al. (2014), who evaluated the effect of management of fungicide application on the physiological and sanitary quality of soybean seeds. The authors found a linear response with an increase in the number of applications. Carvalho et al. (2013) also found best results in the quality of soybean seeds from the maximum number of applications tested. Moreover, an increase in the number of foliar applications has reportedly been successful for enhancing the seed quality of other crops, such as rice (Telo et al., 2012).

Increasing the number of applications of fungicides resulted in higher quality of the seeds in the two periods of evaluation; however, better results were observed when seeds were evaluated soon after harvest. A higher number of applications led to an increase in germination of approximately $10 \%$ and an increase in seed vigor from $9 \%$ to $20 \%$.

Considering that seeds are the prime input for establishing crops and that they have high added value, these results are expressive. The greater seed quality is, the more profit the seed producer will have. Gains in seed quality of any type are essential in the seed sector because production of high quality soybean seeds is a challenge for the sector, especially in tropical and subtropical regions. In these regions, production of these seeds is only possible through adoption of special techniques. When these techniques are not used, inferior quality is the result (França Neto et al., 2007).

\section{Phenotype correlation}

Estimates of phenotypic correlations between the number of applications and the other traits were mostly of high magnitude (Table 3 ). As expected, estimates were positive and high $(r \geq 0.99)$ between the number of fungicide applications and germination in paper or sand substrates, emergence, the emergence speed index, electrical conductivity, accelerated aging, and seed vigor and viability in the tetrazolium test. Knowledge of association between traits is of great importance in field research studies, especially when measuring or identifying one of the traits is difficult (Cruz et al., 2012).

\section{Incidence of pathogens in seeds}

From the plant health perspective, the ideal seed would be free of any undesirable microorganism. However, this is not always possible since seed quality is highly affected by the climate/weather conditions under which they are produced and stored. In addition, these conditions vary from year to year and from one region to another (Juliatti et al., 2003). In this respect, results show that the seeds produced in the municipality of ljaci had higher proportions of pathogens, which confirms the results of physiological quality for this location (Table 3 ). ljaci received higher rainfall in the crop field, especially in the reproductive stage (Figure 1), $227 \mathrm{~mm}$ more accumulated rainfall, on average. Comparing the evaluation periods, newly harvested seeds stand out with a higher incidence of pathogens than stored seeds. However, comparing only stored seeds, there was no difference in the proportion of pathogens between the production locations (Figure 4).

In the soybean seeds evaluated, seven pathogens were identified, namely: Colletotrichum sp., Phomopsis sp., Fusarium sp., Alternaria sp., Cercospora kikuchii, Penicilium $s p$., and Aspergillus sp. The proportion of pathogens (considering the mean of the crop locations), according to analysis of the confidence interval for proportions, shows a higher incidence of Cercospora kikuchii (41.89\%) in newly harvested seeds and Aspergillus sp. (51.45\%) in seeds stored for 8 months (Figures $5 \mathrm{~A}$ and $\mathrm{B}$ ). There was also a higher incidence of field pathogens in newly harvested seeds (Figure $5 \mathrm{~A}$ ); in stored seeds, there was a higher incidence of pathogens that develop better under storage conditions, as is the case of Aspergillus $s p$. and Penicilium sp. (Figure $5 \mathrm{~B}$ ). For the products used for newly harvested seeds, lower proportions of pathogens were observed when the commercial products Fox, Orkestra, and Opera were used (Figure 5 C), with a mean incidence of pathogens below $20 \%$. The same was not observed for seeds stored for eight months, in which no difference was found among the products used (Figure $5 \mathrm{D}$ )

In relation to the number of applications, the same response was observed among the newly harvested seeds and those stored for 8 months. Higher proportions of pathogens were found for the control that did not receive any fungicide application and for the treatments with only one application. From the second to the fifth application, there was a linear decrease in the incidence of pathogens (Figures $5 \mathrm{E}$ and $\mathrm{F}$ ), however, without a significant difference among the. 
Table 1. Nutrient content of the soil layer $(0-20 \mathrm{~cm})$ in ljaci and Lavras, MG, before the experiments, during the 2014/15 crop year.

\begin{tabular}{|c|c|c|c|c|c|c|c|c|c|c|c|}
\hline \multirow{2}{*}{ Environment } & \multirow{2}{*}{$\begin{array}{l}\mathrm{pH} \\
\mathrm{H}_{2} \mathrm{O}\end{array}$} & $\mathrm{Ca}^{2+}$ & $\mathrm{Mg}^{2+}$ & $\mathrm{Al}^{3+}$ & $\mathrm{H}^{+}+\mathrm{Al}^{3+}$ & SB & CEC & $P$ & $\mathrm{~K}$ & \multirow{2}{*}{$\begin{array}{l}\mathrm{OM} \\
\mathrm{dag} / \mathrm{kg}^{-1}\end{array}$} & \multirow{2}{*}{$\begin{array}{l}\mathrm{V} \\
\%\end{array}$} \\
\hline & & \multicolumn{6}{|c|}{---o-- $\mathrm{cmol}_{\mathrm{c}} \mathrm{dm}^{-3}$} & \multicolumn{2}{|c|}{$-\mathrm{mg} \mathrm{dm}^{-3}-$} & & \\
\hline ljaci & 6.3 & 5.0 & 1.8 & 0 & 2.9 & 6.7 & 9.6 & 28.4 & 118 & 5.4 & 69.8 \\
\hline Lavras & 6.2 & 3.8 & 0.8 & 0 & 0.9 & 4.8 & 5.7 & 20.8 & 92 & 2.2 & 83.5 \\
\hline
\end{tabular}

$\mathrm{H}+\mathrm{Al}$ : potential acidity; SB: sum of bases; CEC: cation exchange capacity at pH 7.0; OM: organic matter; V: base saturation.
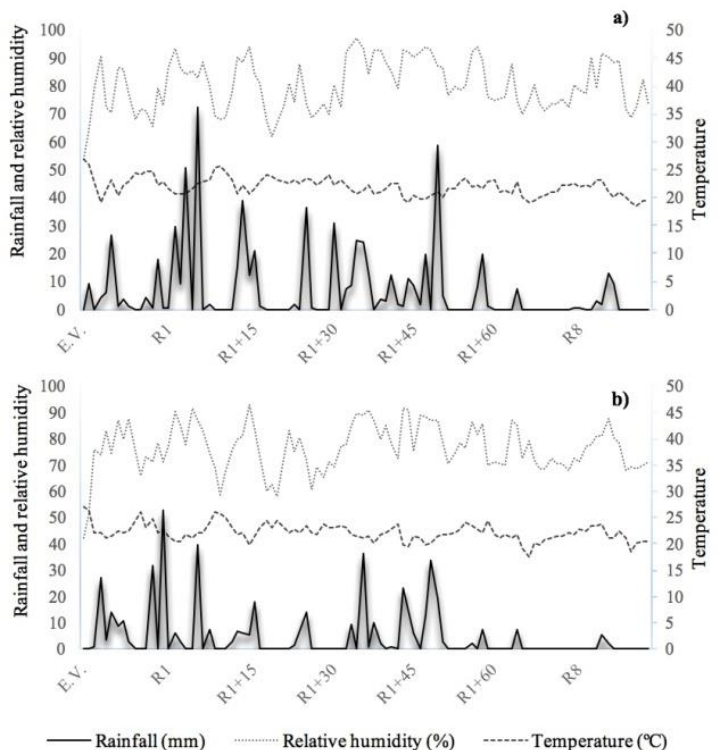

Fig 1. Rainfall daily averages, temperature, and relative air humidity in ljaci (a) and Lavras (b), Minas Gerais, during the 2014/15 crop year at the time of fungicide applications. Source: National Institute of Meteorology (INMET). E.V. vegetative phase. $R_{1}-$ beginning of bloom (1st application).

Table 2. Number of fungicide applications used in the development stages of soybean.

\begin{tabular}{lc}
\hline Number of Applications & Phenological stage at application \\
\hline 0 & No application (Control) \\
1 & $R_{1}{ }^{*}$ \\
2 & $R_{1}$ and $R_{1}+15$ days** \\
3 & $R_{1}, R_{1}+15$ e $R_{1}+30$ \\
4 & $R_{1}, R_{1}+15, R_{1}+30$ and $R_{1}+45$ \\
5 & $R_{1}, R_{1}+15, R_{1}+30, R_{1}+45, R_{1}+60$ \\
\hline * Beginning of Bloom, ${ }^{* *}$ Days after $R_{1}$. &
\end{tabular}

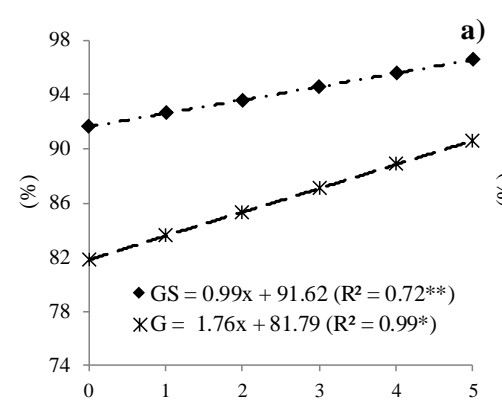

b)

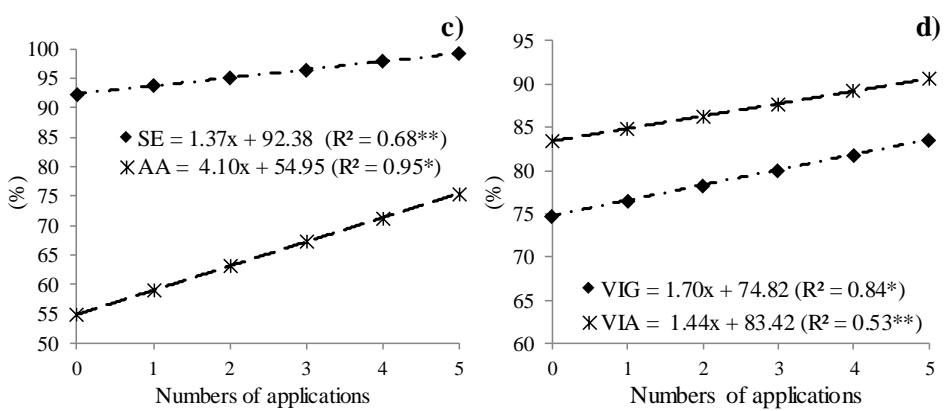

Fig 2. Regression analysis for germination in sand and germination (a), emergence speed index (b), seedling emergence and accelerated aging (c), and vigor and viability - Tetrazolium (d) for evaluation of newly harvested seeds subjected to different numbers of applications of foliar fungicides in the 2014/2015 crop year in the municipalities of Lavras and ljaci, MG, Brazil. 
Table 3. Mean values and phenotypic correlation $(r)$ between the number of applications and water content (\%), germination in sand (\%), germination (\%), seedling emergence (\%), emergence speed index, mechanical damage by the sodium hypochlorite test (\%), electrical conductivity $\left(\mu \mathrm{S} . \mathrm{cm}^{-1} \cdot \mathrm{g}^{-1}\right)$, accelerated aging (\%), and seed vigor (\%) and viability (\%) by the tetrazolium test in relation to the sources of variation in the 2014/2015 crop year in the municipalities of Lavras and ljaci, MG, Brazil.

\begin{tabular}{|c|c|c|c|c|c|c|c|c|c|c|c|}
\hline Source of variation & $\begin{array}{l}\text { Water } \\
\text { content }\end{array}$ & Germination in sand & Germination & Seedling emergence & $\begin{array}{l}\text { Emergence } \\
\text { index }\end{array}$ & speed & $\begin{array}{l}\text { Mechanical } \\
\text { damage }\end{array}$ & $\begin{array}{l}\text { Electrical } \\
\text { conductivity }\end{array}$ & $\begin{array}{l}\text { Accelerated } \\
\text { aging }\end{array}$ & Vigor & $\begin{array}{l}\text { Viabilit } \\
y\end{array}$ \\
\hline Location & Newly ha & & & & & & & & & & \\
\hline Ijaci & $11.1 \mathrm{a}$ & $92.9 \mathrm{~b}$ & $84.8 \mathrm{a}$ & $94.5 \mathrm{~b}$ & $151.1 \mathrm{a}$ & & $6.3 \mathrm{a}$ & $50.5 \mathrm{a}$ & $63.5 \mathrm{~b}$ & $78.8 \mathrm{a}$ & $88.6 \mathrm{a}$ \\
\hline Lavras & $11.0 \mathrm{a}$ & $95.2 \mathrm{a}$ & $87.5 \mathrm{a}$ & $97.1 \mathrm{a}$ & $152.4 \mathrm{a}$ & & $3.7 \mathrm{~b}$ & $41.4 \mathrm{~b}$ & $66.9 \mathrm{a}$ & $79.6 \mathrm{a}$ & $85.4 \mathrm{~b}$ \\
\hline \multicolumn{12}{|l|}{ Fungicide } \\
\hline BAS $-702^{1}$ & $10.9 \mathrm{a}$ & $94.9 \mathrm{a}$ & $84.9 \mathrm{~b}$ & $96.6 \mathrm{a}$ & $152.2 \mathrm{~b}$ & & $4.3 \mathrm{c}$ & $40.0 \mathrm{~d}$ & $65.0 \mathrm{~b}$ & $76.3 \mathrm{~b}$ & $86.5 \mathrm{~b}$ \\
\hline Elatus $^{\circ 2}$ & 10.9 a & $92.8 \mathrm{~b}$ & $83.3 \mathrm{~b}$ & $95.3 \mathrm{~b}$ & $148.6 \mathrm{c}$ & & $4.8 \mathrm{c}$ & $47.0 \mathrm{~b}$ & $61.1 \mathrm{~b}$ & $78.3 \mathrm{~b}$ & $86.3 \mathrm{~b}$ \\
\hline Fox ${ }^{63}$ & $11.2 \mathrm{a}$ & $94.2 \mathrm{a}$ & 88.7 a & 96.9 a & $156.3 \mathrm{a}$ & & $6.8 \mathrm{a}$ & $51.8 \mathrm{a}$ & $71.2 \mathrm{a}$ & $82.1 \mathrm{a}$ & $88.1 \mathrm{a}$ \\
\hline Opera $^{*} 4$ & $11.1 \mathrm{a}$ & $94.6 \mathrm{a}$ & $85.3 \mathrm{~b}$ & $96.0 \mathrm{a}$ & $152.3 \mathrm{~b}$ & & $3.4 \mathrm{~d}$ & $44.4 \mathrm{c}$ & $64.5 \mathrm{~b}$ & $78.3 \mathrm{~b}$ & $86.8 \mathrm{~b}$ \\
\hline Orkestra 5 & $11.0 \mathrm{a}$ & $93.8 \mathrm{a}$ & $88.5 \mathrm{a}$ & $94.1 \mathrm{~b}$ & $149.3 \mathrm{c}$ & & $5.6 \mathrm{~b}$ & $46.5 \mathrm{~b}$ & $64.0 \mathrm{~b}$ & $80.5 \mathrm{a}$ & $87.2 \mathrm{~b}$ \\
\hline $\mathrm{r}$ & - & 1 & 1 & 1 & 1 & & NS & 1 & 1 & 1 & 1 \\
\hline Location & After sto & & & & & & & & & & \\
\hline Ijaci & $10.3 \mathrm{~b}$ & $82.7 \mathrm{~b}$ & $80.1 \mathrm{a}$ & $84.5 \mathrm{a}$ & $65.9 \mathrm{a}$ & & $9.1 \mathrm{a}$ & $46.4 \mathrm{a}$ & $55.3 \mathrm{~b}$ & $69.3 \mathrm{~b}$ & $77.9 \mathrm{~b}$ \\
\hline Lavras & $10.6 \mathrm{a}$ & $87.9 \mathrm{a}$ & $80.4 \mathrm{a}$ & $86.2 \mathrm{a}$ & $58.6 \mathrm{~b}$ & & $7.6 \mathrm{~b}$ & $41.4 \mathrm{~b}$ & $64.2 \mathrm{a}$ & $71.4 \mathrm{a}$ & $82.4 \mathrm{a}$ \\
\hline \multicolumn{12}{|l|}{ Fungicide } \\
\hline BAS $-702^{1}$ & $10.3 \mathrm{a}$ & $87.1 \mathrm{a}$ & $77.1 \mathrm{c}$ & $83.2 \mathrm{c}$ & $58.9 \mathrm{c}$ & & $9.1 \mathrm{a}$ & $44.6 \mathrm{a}$ & $53.4 \mathrm{c}$ & $69.5 \mathrm{a}$ & $79.2 \mathrm{a}$ \\
\hline Elatus $^{2}$ & $10.3 \mathrm{a}$ & $81.3 \mathrm{~b}$ & $76.4 c$ & $81.4 \mathrm{c}$ & $58.4 \mathrm{c}$ & & $7.8 \mathrm{~b}$ & $42.2 \mathrm{a}$ & $56.0 c$ & $69.7 \mathrm{a}$ & $80.1 \mathrm{a}$ \\
\hline Fox $^{3{ }^{3}}$ & $10.6 \mathrm{a}$ & $87.4 \mathrm{a}$ & $85.4 \mathrm{a}$ & $91.4 \mathrm{a}$ & $69.7 \mathrm{a}$ & & $9.6 \mathrm{a}$ & $44.5 \mathrm{a}$ & $68.6 \mathrm{a}$ & $71.9 a$ & $81.0 \mathrm{a}$ \\
\hline Opera ${ }^{4}$ & $10.2 \mathrm{a}$ & 85.4 a & $80.7 \mathrm{~b}$ & $83.9 \mathrm{c}$ & $59.7 \mathrm{c}$ & & $7.3 \mathrm{~b}$ & $43.3 \mathrm{a}$ & $58.8 \mathrm{c}$ & $70.4 \mathrm{a}$ & $80.2 \mathrm{a}$ \\
\hline Orkestra 5 & $10.9 \mathrm{a}$ & $85.3 \mathrm{a}$ & $81.6 \mathrm{~b}$ & $87.0 \mathrm{~b}$ & $64.6 \mathrm{~b}$ & & $8.0 \mathrm{~b}$ & $44.9 \mathrm{a}$ & $62.0 \mathrm{~b}$ & $70.1 \mathrm{a}$ & $80.3 \mathrm{a}$ \\
\hline$r$ & $=$ & 1 & 0.99 & 1 & 1 & & NS & 1 & 1 & 1 & 1 \\
\hline
\end{tabular}

Mean values followed by the same lowercase letter in the column belong to the same group by the Scott Knott (1974) test at $5 \%$ probability. (r) Phenotypic correlation. ${ }^{1}$ BAS -702 (pyraclostrobin + epoxiconazole + fluxapyroxad), ${ }^{2}$ Elatus ${ }^{\circ}$ (azoxystrobin + benzovindiflupyr), ${ }^{3}$ Fox (trifloxystrobin + prothioconazole), ${ }^{4}$ Opera ${ }^{\circ}$ (pyraclostrobin + epoxiconazole), ${ }^{5}$ Orkestra (pyraclostrobin + fluxapyroxad).
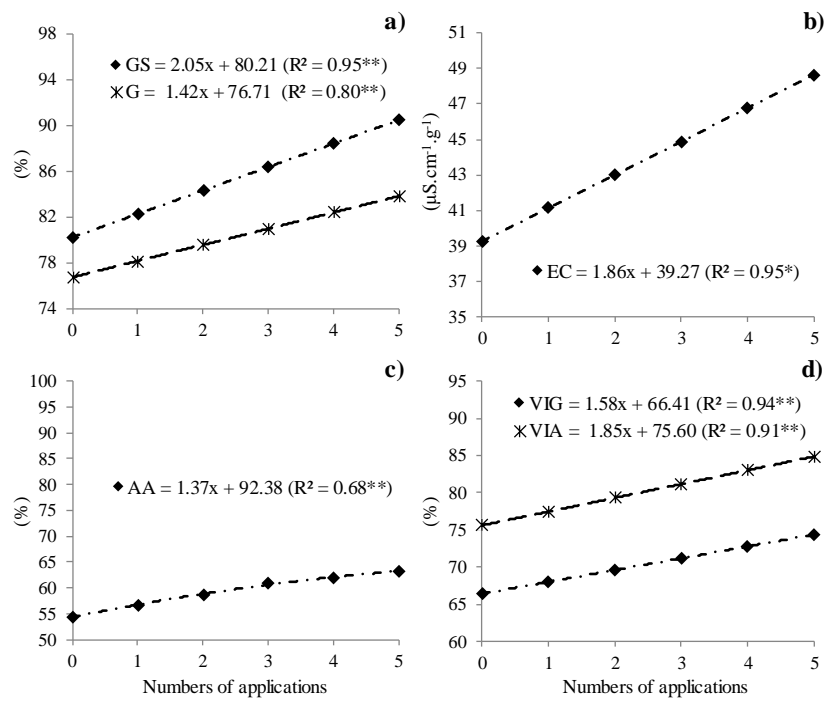

Fig 3. Regression analysis for germination in sand and germination (a), electrical conductivity (b), accelerated aging (c), and vigor and viability - Tetrazolium (d) for seeds stored for 8 months subjected to different numbers of applications with foliar fungicides in the $2014 / 2015$ crop year in the municipalities of Lavras and ljaci, MG, Brazil.

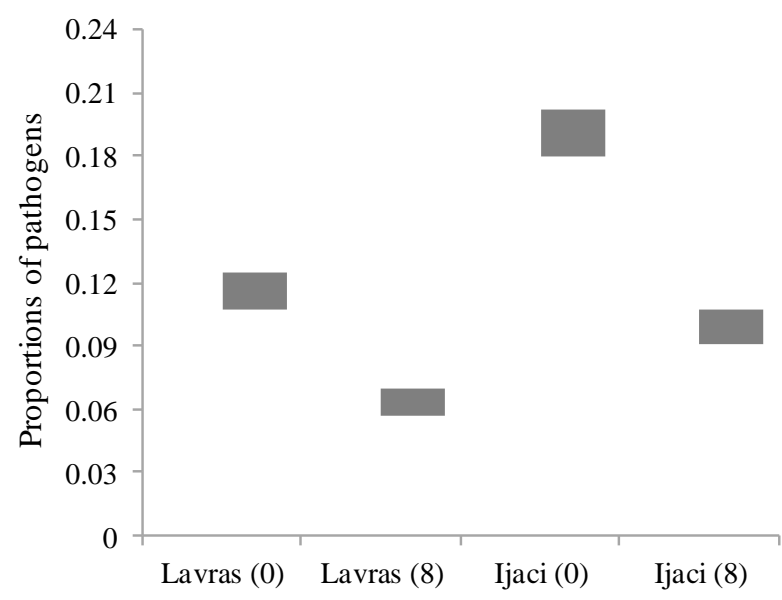

Locations (Months of Storage)

Fig 4. Proportions of pathogens present in soybean seeds newly harvested (0) and stored for 8 months (8) in the 2014/2015 crop year in the crop environments of Lavras and ljaci, MG, Brazil. 

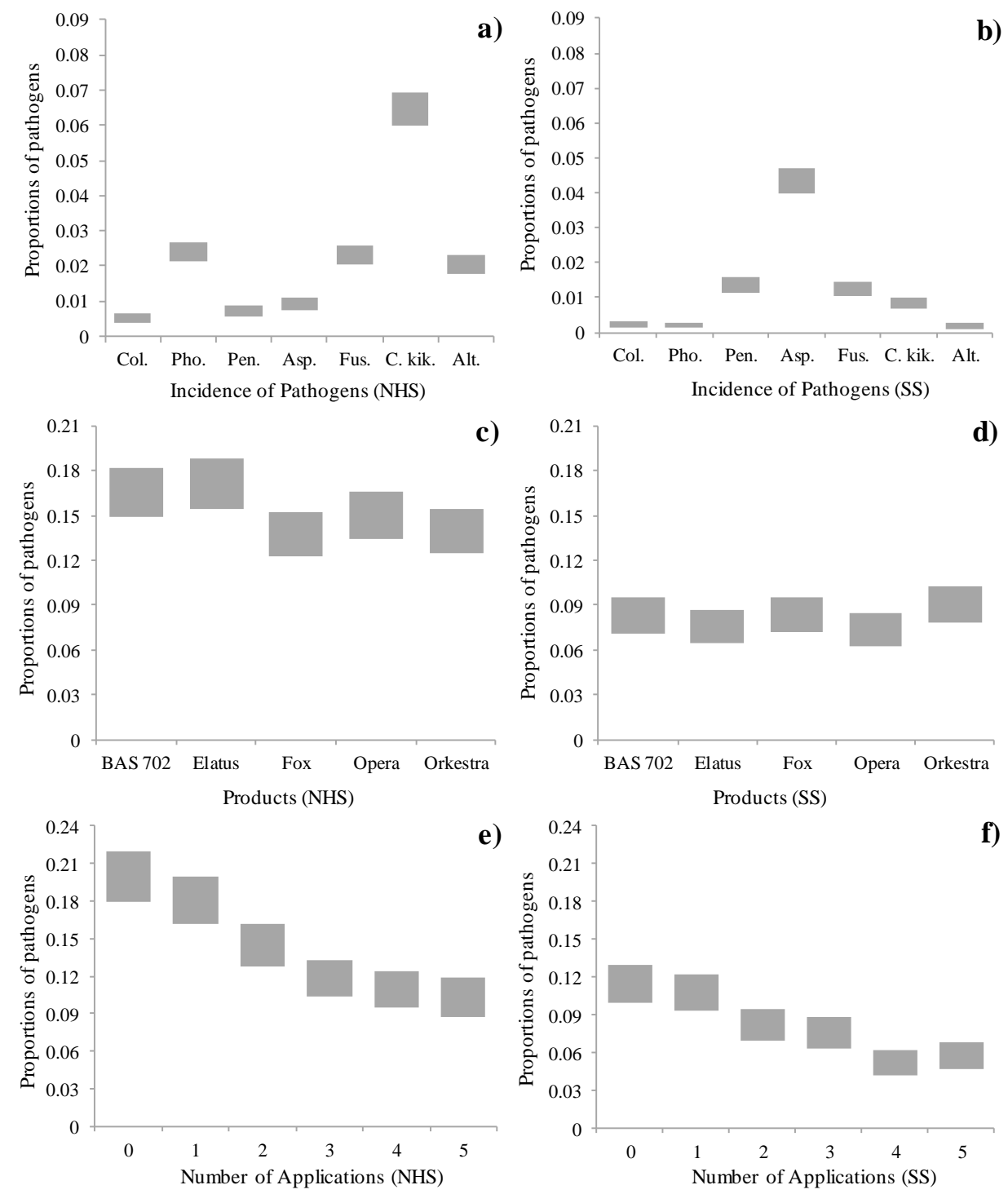

Fig 5. Proportions of pathogens (Colletotrichum - Col., Phomopsis - Pho., Penicilium - Pen., Aspergillus - Asp., Fusarium - Fus., Cercospora kikuchii - C. kik., and Alternaria - Alt.) in NHS (a) and SS (b) using different fungicide products NHS (c) and SS (d) subjected to different numbers of applications for NHS (e) and SS (f), considering the mean of the environments in the 2014/2015 crop year in the municipalities of Lavras and ljaci, MG, Brazil. ${ }^{11} \mathrm{NHS}-$ Newly harvested seeds, ${ }^{2} \mathrm{SS}-$ Stored Seeds.

treatments. These results are contrary to those presented by Gabriel et al. (2014), who evaluated the effect of management of fungicide application on the physiological and sanitary quality of soybean seeds. These authors affirm that the health of soybean seeds was not affected by the number of applications of fungicide

\section{Materials and Methods}

\section{Description of the study environments}

The experiment was conducted in the $2014 / 15$ crop season in two different environments in the state of Minas Gerais, Brazil: on a farm in the municipality of Lavras at $21^{\circ} 14^{\prime} \mathrm{S}$, $45^{\circ} 00^{\prime} \mathrm{W}$, altitude of $918 \mathrm{~m}$, in a soil classified as a Latossolo Vermelho Distroférrico típico; and on a farm in the municipality of ljaci, at $21^{\circ} 09^{\prime} \mathrm{S}, 44^{\circ} 55^{\prime} \mathrm{W}$, altitude of $843 \mathrm{~m}$, in a soil classified as a Latossolo Vermelho-Amarelo distrófico típico. The chemical attributes of the $0-20 \mathrm{~cm}$ soil layer for the two environments are shown in Table 1.

Climate in the region is Cwa according to the Köppen classification, with mean annual temperature of $19.3^{\circ} \mathrm{C}$ and normal annual rainfall of $1530 \mathrm{~mm}$ (Dantas et al., 2007). The daily climate data from the beginning of fungicide applications (Figure 1) were made available by the National Meteorological Institute (Instituto Nacional de Meteorologia - INMET).

\section{Experimental design and trial management}

In the seed production field, the experiments were conducted in a randomized block design in split-plots, with three replications. Plots were constituted by the number of applications (Table 2), and the split-plots were constituted by different chemical fungicides: Elatus (azoxystrobin + benzovindiflupyr), Fox (trifloxystrobin + prothioconazole), 
Opera (pyraclostrobin + epoxiconazole), Orkestra ${ }^{\bullet}$ (pyraclostrobin + fluxapyroxad), and the unregistered product BAS - 702 (pyraclostrobin + epoxiconazole + fluxapyroxad). The experimental plots consisted of 4 plant rows of 5-meter length spaced at $0.50 \mathrm{~m}$, and the area of each plot was $10 \mathrm{~m}^{2}(5 \mathrm{~m} \times 2 \mathrm{~m})$. The two center rows were considered the useful area, disregarding the $0.5 \mathrm{~m}$ at the ends of each plot.

The experiments were performed in an area under a notillage system over corn straw, with previous desiccation of the area using 960 g.ha ${ }^{-1}$ of the active ingredient glyphosate. Sowing was performed in the first half of November in the two production environments. The cultivar BRSMG $850 G_{R R}$ was used, which has a determined growth habit and belongs to the relative maturity group 8.2 , with a semi-late cycle (126 to 145 days) in the state of Minas Gerais. Fertilization followed the recommendations of Souza and Lobato (2004), with application of $350 \mathrm{~kg} / \mathrm{ha}^{-1}$ of the $\mathrm{N}-\mathrm{P}_{2} \mathrm{O}_{5}-\mathrm{K}_{2} \mathrm{O}(02-30-20)$ formulation in the planting furrow. Inoculation was made in the furrow after sowing, according to the methodology recommended by Embrapa (2013), with Bradyrhizobium japonicum bacteria at the rate of $18 \mathrm{~mL}$ of product $\mathrm{kg}^{-1}$ of seed - SEMIA 5079 and 5080 strains, containing $10.8 \times 10^{6}$ $\mathrm{CFU} /$ seed of the inoculant Nitragin Cell Tech $\mathrm{HC}^{\circ}\left(3 \times 10^{9}\right.$ $\mathrm{CFU} / \mathrm{mL}$ ).

Pest and weed control was carried out according to the technical recommendations for the soybean crop (EMBRAPA, 2013). Fungicides were applied using a backpack sprayer pressured by $\mathrm{CO}_{2}$, equipped with a two-meter boom with four Teejet XR 11002 spray nozzles spaced at $50 \mathrm{~cm}$ and calibrated for a flow rate of 200 liters $\mathrm{ha}^{-1}$. At the time of application, the adjuvant recommended by the manufacturer was added at the rate recommended for each fungicide.

The experiments were harvested manually and threshed mechanically using the plot thresher MAQTRON Vencedora model B - 350 STD. The seed samples in each plot were homogenized and classified by sieving. For analyses and determinations, seeds retained in 6.5 and $7 \mathrm{~mm}$ mesh circular sieves were used. Part of the seeds were separated for initial analysis of quality, and the rest were placed in multi-layered paper packaging and stored for eight months in an environment with constant temperature of $25 \circ \mathrm{C}$.

\section{Evaluations carried out}

For determination of quality before and after storage, seeds were subjected to the following evaluations: Water content: performed according to Brasil (2009), using the standard laboratory oven method at $105^{\circ} \mathrm{C} \pm 3^{\circ} \mathrm{C}$ for $24 \mathrm{~h}$, with the results expressed in percentage. Germination: performed according to Brasil (2009), evaluated in paper and sand substrate. Seedling emergence: seeds were sown in plastic trays containing soil + sand substrate at a 2:1 proportion, moistened to $60 \%$ of water retention ability - the trays were kept in a growth chamber at $25^{\circ} \mathrm{C}$ and 12 hour photoperiod, with daily evaluations in regard to emergence of normal seedlings and final count at 14 days after sowing. The final percentage of emergence and the emergence speed index, ESI, were considered (Maguire, 1962). Electrical conductivity: was carried out according to Kryzanowski et al. (1999), with assistance of a conductivity meter (MS TECNOPON ${ }^{\circ}$ - mCA150), and results were expressed in $\mu \mathrm{S} . \mathrm{cm}^{-1} \cdot \mathrm{g}^{-1}$. Accelerated aging: with the use of adapted Gerbox plastic boxes with a suspended aluminum screen $40 \mathrm{~mL}$ of water and a single layer of seeds were added over the screen in each Gerbox, which were then kept in a BOD chamber at $41^{\circ} \mathrm{C}$ for 48 hours (Marcos Filho, 1999). After this period, the seeds were subjected to the germination test (Brasil, 2009). Tetrazolium test: seeds were placed between moistened paper for $16 \mathrm{~h}$ at $25^{\circ} \mathrm{C}$ and then immersed in tetrazolium solution (2,3,5-triphenyl-2 $\mathrm{H}$-tetrazolium chloride) at $0.075 \%$, in which the seeds remained for $3 \mathrm{~h}$ at $40^{\circ} \mathrm{C}$, in the dark. The result was expressed by the percentage of vigor and viability (verified at levels 1 to 8 ), according to França Neto et al. (1998). Mechanical damage: through the sodium hypochlorite test according to the criteria described by Krzyzanowski et al. (2004). The samples were placed in a container and immersed in a sodium hypochlorite solution (5.25\%) for 10 minutes. After that, the seeds were placed on sheets of paper towel, and the number of seeds that exhibited a seed coat that was ruptured and loose were analyzed. The results were expressed in percentage of seeds with mechanical damage. Seed health: for analysis of seed health, the blotter test method was used, with five replications of 40 seeds that were placed in Petri dishes over three sheets of paper, according to Limonard (1966), moistened with water + 2,4D (2,4-Dichlorophenoxyacetic acid) at $0.02 \%$, and kept in an incubation chamber at a temperature of $20 \pm 2^{\circ} \mathrm{C}$ and 12 hour photoperiod for seven days. Evaluations were made of individual seeds with the assistance of a stereomicroscope and optical microscope to detect the presence of pathogens associated with seeds.

\section{Statistical Analysis}

Combined analysis of variance was carried out, adopting the statistical model and the analytical procedure similar to those presented by Ramalho et al. (2012). Qualitative factors were clustered by the Scott-Knott (1974) test. Regression analysis was applied to study the sources of quantitative variation. Seed health was analyzed through the confidence interval for proportions, as performed by Zambiazzi et al. (2017) by the Poisson approximation at the level of $5 \%$ significance. Analyses were carried out assisted by the SISVAR ${ }^{\circ}$ statistical package (Ferreira, 2014). Phenotypic correlation between the number of applications and the traits related to seed physiological quality was also estimated (Cruz et al., 2012) assisted by the SAS 9.0 statistical program from Statistical Analysis Systems (2008).

\section{Conclusion}

The fungicide Fox (trifloxystrobin + prothioconazole) applied on leaves during the reproductive stages of the soybean crop provided the best results for physiological quality of newly harvested seeds and those stored for eight months, as well as for the sanitary quality of newly harvested seeds. An increase in the number of applications of foliar fungicides, up to five applications, leads to an increase in the physiological and sanitary quality of soybean seeds, both those newly harvested and those stored for eight months. 


\section{Acknowledgments}

The authors thank the FAPEMIG (Fundação de Amparo à Pesquisa do Estado de Minas Gerais), the CNPq (Conselho Nacional de Desenvolvimento Científico e Tecnológico), and the CAPES (Coordenação de Aperfeiçoamento de Pessoal de Nível Superior) for granting scholarships and financial support.

\section{References}

Azevedo LAS (2001) Proteção Integrada de Plantas com Fungicidas: teoria, prática e manejo. São Paulo.

Bethenod O, Corre ML, Huber L, Sache I (2005) Modelling the impact of brown rust on wheat crop photosynthesis after flowering. Agric For Meteorol. 131(5):41-53.

Brasil. Ministério da Agricultura, Pecuária e Abastecimento (2009) Regras para análise de sementes, Brasília.

Brzezinski CR, Abati J, Henning FA, França-Neto JB, Henning AA (2012) Eficiência de fungicidas para controle da ferrugem asiática da soja e sua influência na produtividade e na qualidade de sementes. Inf Abrates. 22(3):84-87

Canedo SC, Fagan EB, Teixeira WF, Soares LH, Silva LG, Silva MA (2013) Qualidade fisiológica de sementes de soja obtidas de plantas tratadas com piraclostrobina. Cerrado Agroc. 4:98-107.

Carmona MA, Reis EM (2009) Critério: sistema de pontuação para aplicação de fungicidas para as doenças de final de ciclo na cultura da soja. In: Reis EM (ed.). Critérios indicadores do momento para aplicação de fungicidas visando ao controle de doenças em soja e trigo. Passo Fundo: Aldeia Norte Editora, 2009.

Carraro IM, Peske ST (2005) Uso de sementes de soja no Estado do Paraná. Rev. Bras. Sementes, 27(2):75-80.

Cruz CD, Regazzi AJ, Carneiro PCS (2012) Modelos biométricos aplicados ao melhoramento genético. v. 1, 4.ed. Viçosa: UFV.

Danelli AL, Fiallos FRG, Tonin RB, Forcelini CA (2011) Qualidade sanitária e fisiológica de sementes de soja em função do tratamento químico de sementes e foliar no campo. Rev Cienc Tecnol. 4(2):29-37.

Dantas AA, Carvalho LG, Ferreira E (2007) Classificação e tendências climáticas em Lavras, MG. Ciênc Agrotec. 31(6):1862-1866.

Dourado Neto D, Oliveira RF, Begliomini E, Rodrigues MAT (2005) F500 em soja e milho: efeitos fisiológicos comprovados. Atual Agríc. 5:12-16.

EMBRAPA. Empresa Brasileira de Pesquisa Agropecuária (2010) Centro Nacional de Pesquisa de Soja. Tecnologias de produção de soja - região central do Brasil Londrina: Embrapa Soja: Embrapa Cerrados: Embrapa Agropecuária Oeste.

EMBRAPA. Empresa Brasileira de Pesquisa Agropecuária (2013) Tecnologias de produção de soja - Região Central do Brasil 2014. Embrapa Soja: Londrina.

Ferreira DF (2014) Sisvar: A computer statistical analysis system. Ciênc Agrotec. 38(2):109-112.

Finoto EL, Carrega WC, Sediyama T, Albuquerque JAA, Cecon PR, Reis MS (2011) Efeito da aplicação de fungicida sobre caracteres agronômicos e severidade das doenças de final de ciclo na cultura da soja. Rev. Agro@mbiente. 5(1):4449.
França Neto JB, Krzyzanowski FC, Henning AA (2010) A importância do uso de sementes de soja de alta qualidade. Inf Abrates. 20(1-2): 37-38.

França-Neto JB, Krzyzanowski FC, Costa NP (1998) O teste de tetrazólio em sementes de soja. Londrina, Embrapa Soja.

França-Neto JB, Krzyzanowski FC, Pádua GP, Costa NP, Henning AA (2007) Tecnologia para produção de sementes de soja de alta qualidade Série Sementes. Londrina, Embrapa Soja.

Gabriel M, Rosa GM, Kulczynski SM, Roppa A, Silva JC, Volpatto $F$ (2014) A influência do manejo de aplicação de fungicida sobre a produtividade, qualidade fisiológica e sanitária de sementes de soja. In: Anais do Salão Internacional de Ensino, Pesquisa e Extensão. Bagé, Rio Grande do Sul, 2014.

Gagliardi B, Carvalho TC, Pupim TL, Gomes Junior FG, Timóteo TS, Kobori NN, Moraes MHD, Menten JOM (2009) Efeito de fungicidas para controle da ferrugem asiática na qualidade de sementes de soja. Rev Bras Sementes. 31(4):120-125.

Juliatti FC, Junior RDB, Martins JAS (2011) Qualidade fisiológica e sanitária de sementes de algodoeiro produzidas nas regiões do Triângulo Mineiro e sul de Goiás. Biosc J. 27(1):24-31.

Krzyzanowski FC, Vieira RD, França Neto JB (1999) Vigor de sementes: conceitos e testes. Associação Brasileira de Tecnologia de Sementes, Comitê de Vigor de Sementes, Londrina, Abrates.

Krzyzanowski FC, França Neto JB, Costa NP (2004) Teste do Hipoclorito de Sódio para Semente de Soja. Londrina, Embrapa Soja.

Krzyzanowski FC, Henning AA, França Neto JB, Lorini I, Henning FA, Gazziero DLP (2015) Tecnologias para Produção de Sementes de Soja. Londrina, Embrapa Soja.

Limonard TA (1966) Modified blotter test for seed health. Neth J Plant Pat. 72:319-321.

Maguire JD (1962) Speed of germination - aid in selection and evaluation for seedling emergence and vigor. Crop Sci. 2(2):176-177.

Marcos Filho J (1999) Teste de envelhecimento acelerado. In: Krzyzanowski FC, Vieira RD, França Neto JB (ed.). Vigor de sementes: conceitos e testes. Londrina, Abrates.

Martins MC (2009) Relato da situação da ferrugem e do vazio sanitário no Norte e Nordeste. http://www.consorcioantiferrugem.net/portal//wpconten t/uploads/2010/04/2009_relato_norte_nordeste.pdf. (accessed 20 Jan. 2016).

Marzari V, Marchezan E, Silva LS, Villa SCC, Santos FM, Teló GM (2007) População de plantas, dose de nitrogênio e aplicação de fungicida na produção de arroz irrigado. II. Qualidade de grãos e sementes. Ciênc Rural. 37(4):936941.

Mavaieie DPR (2014) Desempenho de sementes de diferentes cultivares de soja tratadas e não tratadas armazenadas em diferentes condições. Dissertação de mestrado. Lavras, Universidade Federal de Lavras.

Oliveira JA, Carvalho MLM, Vieira MGGC, Von Pinho EVR (1999) Comportamento de sementes de milho colhidas por diferentes métodos, sob condições de armazém convencional. Ciênc Agrotec. 23(2):289-302. 
Pinto TLF, Cicero SM, Neto F, Barros J, Neto DD, Forti VA (2011) Fungicidas foliares e a doença ferrugem asiática na produção e na qualidade de sementes de soja. Rev Bras Sementes. 33(4):680-688.

Quinebre SR (2014) Aplicação de fungicidas no manejo de doenças de soja. Rev Attalea Agron. ed. 98.

Ramalho MAP, Ferreira DF, Oliveira AC (2012) Experimentação em genética e melhoramento de plantas. Lavras: Editora: UFLA, 3 ed.

SAS (2009) Statistical analysis software. version 9.2. SAS Inst.,Cary, NC.

Scott AJ, Knott MA (1974) Cluster analysis method for grouping means in the analysis of variance. Biometrics. 30(3):507-512.

Silveira HF (2010) Taxa de utilização de sementes de soja no estado de Mato Grosso. Dissertação de Mestrado. Pelotas, Universidade Federal de Pelotas.

Souza DMG, Lobato E (2004) Cerrado: correção do solo e adubação. 2a ed. Brasília, Embrapa Cerrados.
Teló GM, Marchesan E, Menezes N, Ferreira RB, Sartori GMS, Formentini TC, Hansel DSS (2012) Aplicação de fungicida em cultivares de arroz irrigado e seu efeito na qualidade de sementes. Rev Bras Sementes. 34(1):99-107.

Vello NA, Carvalho RSB (2013) Melhoramento da soja para resistência genética a doenças In: Grupo de Estudos Avançados em Fitopatologia, GEAFIT, Universidade Federal de Viçosa (Eds.). (Org.). Melhoramento genético no manejo de doenças de plantas. 1 ed. Visconde do Rio Branco, MG: Suprema, 1.

Vitti AJ, Paiva SB, Castrro RM, Veiga JS, Garcia L (2004) Efeito residual e curativo de fungicidas para o cotrole de ferrugem da soja (Phakopsora pachyrhizi). Fitopat Bras. 29:290.

Zambiazzi EV, Bruzi AT, Zuffo AM, Soares IO, Mendes AES, Teresani ALR, Gwinner R, Carvalho JPS, Moreira SG (2017) Desempenho agronómico e qualidade sanitária de sementes de soja em resposta à adubação potássica. Ver. Ciênc Agrárias, 40(2):543-553. 